\title{
Introverted and knotted spaces within modern and contemporary urban fabrics: passages, gallerias and covered squares
}

\author{
Pina Ciotoli, Marco Falsetti \\ Department DiAP. Faculty of Architecture, \\ University of Rome "Sapienza", Rome, Italy \\ E-mail: ciotoligiusi@gmail.com, levonraisen@libero.it
}

\begin{abstract}
Passages, gallerias and "urban" atriums are morphological configurations of a prevalent phenomenon within modern and contemporary cities, in which there has been a further evolution of the specialized urban fabric. The urban and social changes caused by the Industrial Revolution have modified the relationship between public spaces and urban fabric, by defining new connections between urban organism and covered places-usually devoted to commercial or tertiary functions-. French passages and British arcades have had an active role within the existing fabric, relating their own architectural structures to the buildings (existing or new ones) and to the pre-existing vehicular system. In both those types it is possible to recognize a common morphological substrate, that is a radical answer to analogous problems: passages, arcades, and gallerias are covered walkways due to the modern necessity to have gathering places and commercial areas far away from urban traffic and sheltered from weather. The covered pedestrian walkways experienced in Paris, London, Munich are the first examples of a morphological process that can be called "introversion of the routes", that has been intensified also within the urban dynamics of contemporary cities. Architectural experimentation has led to the construction of unconventional public spaces that, both in linear organical systems (passages, gallerias) and in nodal organisms (urban atrium), are integrated within the urban fabric. The aim of this research is to illustrate the typological development of passages, gallerias, and covered squares, identifying the processual nature of those public spaces and projecting them into a new urban vision.
\end{abstract}

Keywords: Knotting, commercial building typology, covered squares, urban organism, introversion of the routes.

\section{The inner city of arcades and passages} (by Pina Ciotoli)

Covered walkways like French passages, British arcades and Italian gallerias have developed starting from the 19th century ${ }^{1}$ all across the European cities and, towards the end of the century, they also became popular in North America. These architectures are mainly due to the deep urban, social and economic changes triggered by the Industrial Revolution, that modified the relationship between public spaces and urban fabric, by defining new connections between urban organism and covered places -usually devoted to commercial or tertiary functions-. Particularly, it is important to point out the mutation of the functional and perceptional role of the street, which is mainly occupied by vehicles and is no more capable to show a "centralized" nature. According to the morphological definition of the road given by Gianfranco Caniggia and Gianluigi Maffei (Caniggia, Maffei, 1982), we can state that the main axis of the 19th century city are generally 
related to a "splitting" function (Ciotoli, 2016), in fact they are unable to center around the road, the formation of specialized buildings or specialized tissues. In fact, following the thesis of Gianfranco Caniggia, we are able to distinguish between the aggregative and spatial components of the buildings, on the basis of their specific location in the city. Therefore, we can identify specialized buildings - and consequently specialized fabrics -, into nodal or anti-nodal types -, according to their disposition in the central or peripheral areas of the city (for example, a fabric made of offices has different characters and nodality degrees compared to an industrial fabric) (Caniggia, Maffei, 1982). So, according to this "distinctive location", every building, axis or urban space is able to deduce its own specific structure from the history and time. Also, it is important to underline how, within the urban model, we are able to distinguish a hierarchy between all these components, based on the difference between nodal and antinodal axis. We should contextualize all those morphological elements according to the urban centrality of peripherality, so if a road has a specific vocation, like a commercial function, the parallel paths will have a secondary role into the urban hierarchy. We can assert that the covered commercial pathways built in the 19th century, behave like centralized axis in which "the space and its legibility through motion (...)" is related to "the reaching of a node or pole starting from another node or pole" (Strappa, 1995). For all these reasons, it is necessary to distinguish centralized axis from splitting lines; first it is important to say that "the term 'line' is not related to the idea of movement as well as to the readability of the urban structure. Usually the splitting lines, while connecting the internal features of organic systems, close off architectural spaces through the identification of unique spaces, although complementary and necessary for the entire organism", (Ciotoli, 2016). In the particular case of modern European cities, we can observe both these conditions: splitting lines are usually destined to vehicular traffic, instead centralized axes are the ones conformed within the urban fabric and used as commercial streets. This transformation, increasingly linked to the dynamic flows of modern metropolis, has contributed in determining the need of citizens for gathering places expressively dedicated to pedestrian traffic, and therefore sheltered from the weathering. The requirement for covered and closed spaces led to the construction of many interior pedestrian walkways with commercial functions, elements that have an active role within the existing fabric, since they relate their architectural structures to the buildings (existing or new ones) and to the pre-existing vehicular system (Ciotoli, Falsetti 2017).

\section{Introverted spaces}

(by Pina Ciotoli)

Arcades and passages, built in Great Britain and France since the 18th century, can be considered as architectural responses to the metropolitan need of having commercial places far from chaos and vehicular traffic. Johann Friedrich Geist has been one of the first researcher to dwell on the meaning of the term arcade, and on its relative diffusion (of the term and of the architectural type) throughout the world. According to Geist, "the word "arcade" is used (...) to translate the German Passage, a word which expresses the transitional nature of this building type. The German term comes from the French passage, which was used as early as the 18th century to refer to the narrow private streets which divided and connected the interiors of larger building blocks. The root is passus, the Latin word for step, conveying the element of movement, of passage through a space. It has numerous meanings in common linguistic usage: street, roadway, thoroughfare, alley, transit, crossing, part of a book or musical composition, measured gait of a horse, or, in French, the sense of passage de la vie. All these meanings, either spatial or temporal in emphasis, have one element in common: they express transition, threshold, passing, measured distance, or disappearance. Something occurs, comes to pass; movement becomes an event" (Geist, 1983).

For the purpose of a morphological interpretation of this phenomenon, it is important to underline how these structures 
are able to synthesize the so-called process of "internalization of the paths" (Maretto, 1993), for which the distribution of the building is related to the role of the overturned path in the urban fabric. Through this process, the inner road -of the arcade and of the passage- carries out the role of a linear component that catalyzes the congestion and the movement through the gallery. At the same time it defines the kind of aggregation of this typology, since the single units of the building are concentrated along the sides of the covered road, by emphasizing in this way the distribution and the volume of the arcade/passage.

Furthermore the covered street is involved in a process of inversion of the functional dynamics of the metropolis, by realizing a sort of transposition of the modern fervor in a linear architecture; in fact, thanks to the the process of "internalization of the paths" the building framework tightens an organic relationship within the morphology of the urban fabric (in which the inner road is projected).

The inner micro-city of arcades and passages reveals an interesting typological dualism: the controversial relationship between public fruition and private property as well as the intense connection between indoor and outdoor spaces.

It is necessary to underline how these "parallel systems" are involved in the definition of new urban scenarios in which the interior facades of the stores rework the composition and the proportions of the nearby external palaces.

In the reduced dimension of this architectural type, it is interpreted -and reproduced in scale- an idealized view of the 19th century metropolis.

As already mentioned earlier, for a morphological interpretation of this typology we can state that if the streets of the 19th century increasingly demonstrate a "splitting" function, being unable to concentrate around their ways specialized buildings or specialized fabrics, instead French passages and British arcades are "linked to the housing unit on which they are built. For this reason, the cadastral unit should be considered together with the road system, as the founding element of urban space" (Lemoine, 1989).

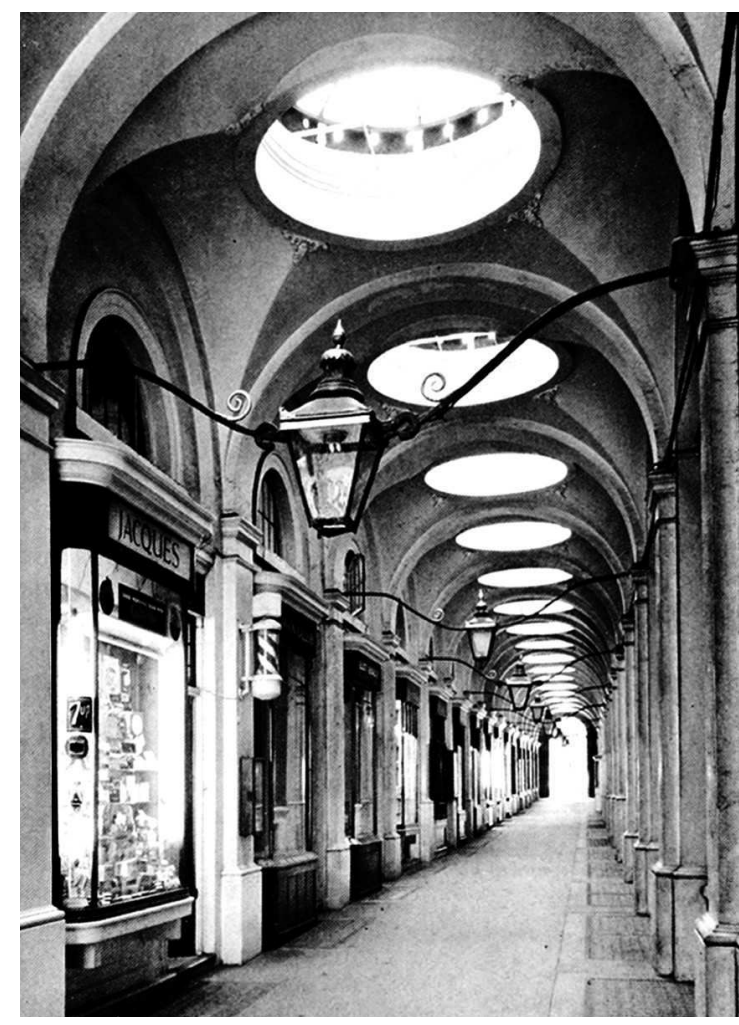

Figure 1.

Royal Opera Arcade, London. Source: Survey of London: Volumes 29 and 30, St James Westminster, Part 1, ed. F H W Sheppard (London, 1960), British History Online.

Moreover, since covered commercial pathways use to develop within the existing fabric, they can act like an architectural knot (Falsetti, 2016), by linking together new architectures with the existing ones; in fact the inner pathways can be considered as an ideal matrix in the creation of a new kind of space, in which commerce, gathering places and social relations coexist and are related to the urban fabric (Ciotoli, 2017).

\section{Urban Knottings}

(by Marco Falsetti)

If the phenomenon of introversion of the routes was evident for the formation of passages and arcades, an analogous process can still be identified in other architectural examples, in which, the formation of specialized fabrics and buildings is defined through the prevailing action of commercial pathways. In particular we can find that the linear conception of 


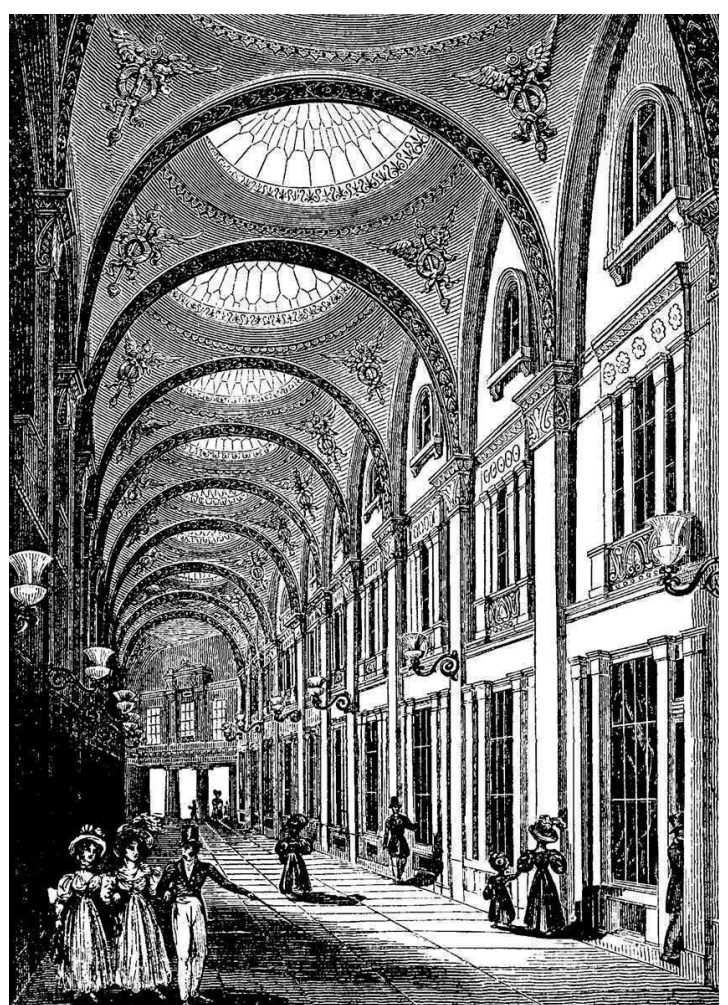

Figure 2.

Lowther Arcade, London. Source: http://londontopia.net

the market space has often led to the rise of peculiar and complex building structures that, over time, have reached an autonomous, typologically codified extension.

The market-type has in fact evolved processually, from the linear dimension of a path, to whole buildings, organisms that often, due to the progressive extension of the phenomenon, have taken an urban character, involving large sections of fabric: galleries, malls, bazar, passage, arcade, shōtengai have thus been defined according to these aggregative logic, by permanently translating into matter a provisional idea.

These "knotting" processes ${ }^{2}$, transformations of originally temporary and open elements like commercial paths- into buildings, have structured, with different levels of complexity, by developing the typical characters of the fabric in which they were settled. In fact, in the absence of an architectural organism suitable to contain the functional principle, it develops by forming "special" places, lacking a typological determination, but that reflect the characteristics of the place where they are located.

The relationship between knotting and urban fabric is complex since it can be considered, at the same time, cause and effect of the structure of the latter. The knotting can be analyzed as a "specialization" of the building, of the fabric and of the territory (Falsetti, 2016), since it concerns the dialectic between special buildings and urban fabric as stated by Gianfranco Caniggia and Gianluigi Maffei in their essay "Lettura dell'edilizia di base" (translated in English as "Architectural composition and building typology"): "the location of the special buildings in the fabric is both cause and effect of the structuring of the same, and it changes in time and space, with the processuality of the fabric they belong" (Caniggia, Maffei, 1982).

And yet the typological migration of a functional path within the fabric, and the transformation that this involves, is a more ancient phenomenon: starting from the huge colonnaded streets of Syria and Jordan, (Apamea, Gerash, Palmira and Antioch), a whole class of semi-internal urban spaces, linked to the market type, has evolved. The great fortune of such typologies - which structure huge open spaces- in the Mediterranean area, has produced, over time, different families of typo-morphological specialized fabrics like suqs, arastas and bazaars, whose characters have remained unchanged until today.

If we observe nowadays the "Souk Midhat Pascha" in Damascus, we can note how it substantially coincides with the ancient Roman street "via recta", still largely used with a commercial function. The segments included in the market-space, developed, through the centuries, a sort of knotting, and once covered, they became a hybrid form of "buildingfabric". In the Islamic world the phenomenon generally assumes more complex traits, phagocytizing various building typologies like mosques, madras, private palaces, mausoleums and baths. In these cases, a further form of knotting occurs in the building scale, especially where there is a change in the direction of the routes, through the creation of large nodal elements that are vaulted or surmounted by domes, as also noted by Geist 


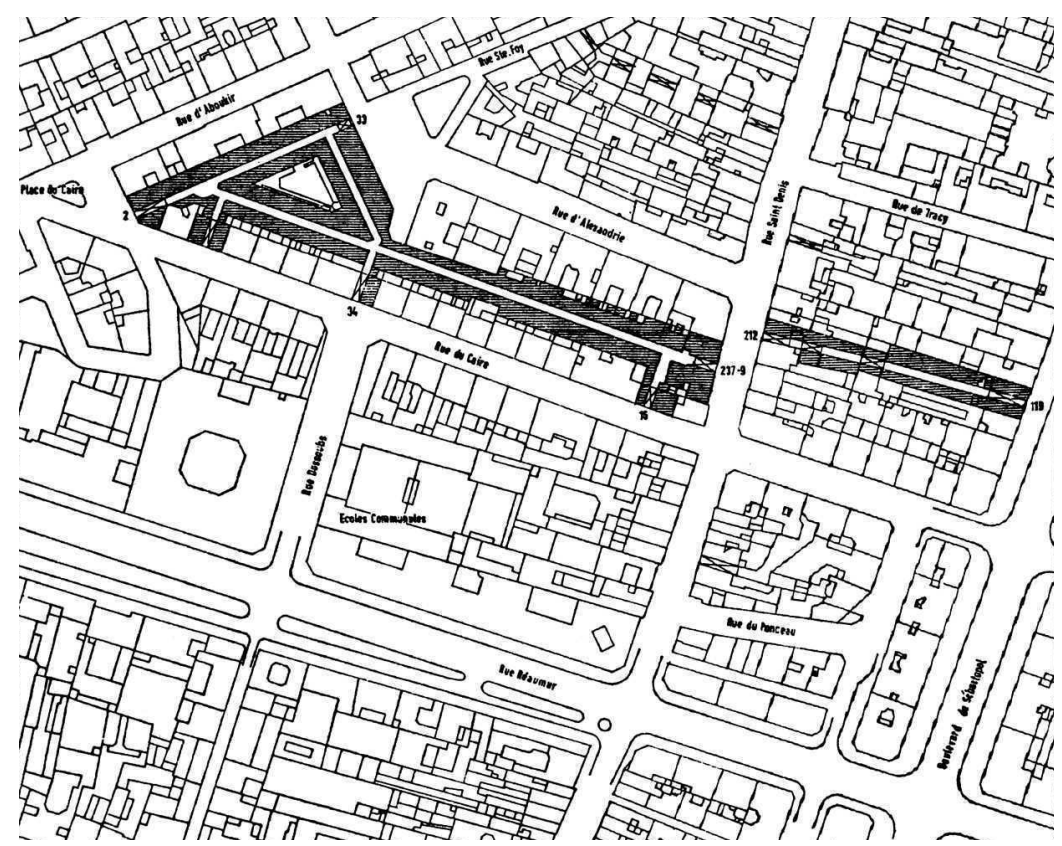

Figure 3.

Passage du Caire, Paris. Source: Geist, J.F. (1983) Arcades: a history of a building type (MIT Press, Cambridge MA).

about the bazaar of Bukhara: "the profile of the streets changes constantly, sometimes enclosed by walls, lined by open shops, or engulfed in large, vaulted bazaars. The streets wind their way between closed blocks constructed in symmetrical and asymmetrical patterns. This example demonstrates that the bazaar need not to be a single building but can also be a main thoroughfare with vehicular traffic" (Geist, 1983).

We can say that the two processes of introversion of the paths and knotting, both related to the formation of commercial spaces, are emphasized at the end of the 19th century, when the advent of vehicular traffic subverted the traditional modes of living the leisure and tertiary activities, forcing them to "retreat" inside the urban fabric. Commercial galleries, department stores and malls represent, in this sense, the architectural response, typologically codified, to this mutation of the outdoor space.

In the 19th century Paris, this condition caused the migration of external pedestrian flows into the interstitial space between the plots, resulting in passages, elements of a wider aggregative typology -the urban knottings- in which the building fabric thickens near the inner paths. It is in fact the passage, which represents the most emblematic form of urban knotting, that assumes, in modern times, the role of primary element for the life of the city and for the configuration of its social spaces.

Nonetheless, although modernity has profoundly transformed the places of leisure by conforming them to its own languages, the aggregative modalities have always been related to archetypal anthropic dynamics, similar between the different cultures. It is not a coincidence that Geist points out that "the sequences of widenings that can be found, with different dimensions and shapes, along the gallery, the inner complexity and the externally closed and introverted structure of the 19th century block, represent the prototype of some recurring types in the evolution of commercial space" (Geist, 1983).

In the knotting process, the archetype of the internal commercial road - produced by the revolution of an original external urban path - defines the formation of a series of hybrid organisms, endowed with both characters. Even in a different and far context like the Japanese one, the diversification of role between the external urban spaces -dedicated to the viability- and the internal urban spaces -dedicated to trade- produces linear organisms linked to the morphology of the city (Osaka, Tokyo, Hiroshima etc) but always connected to 


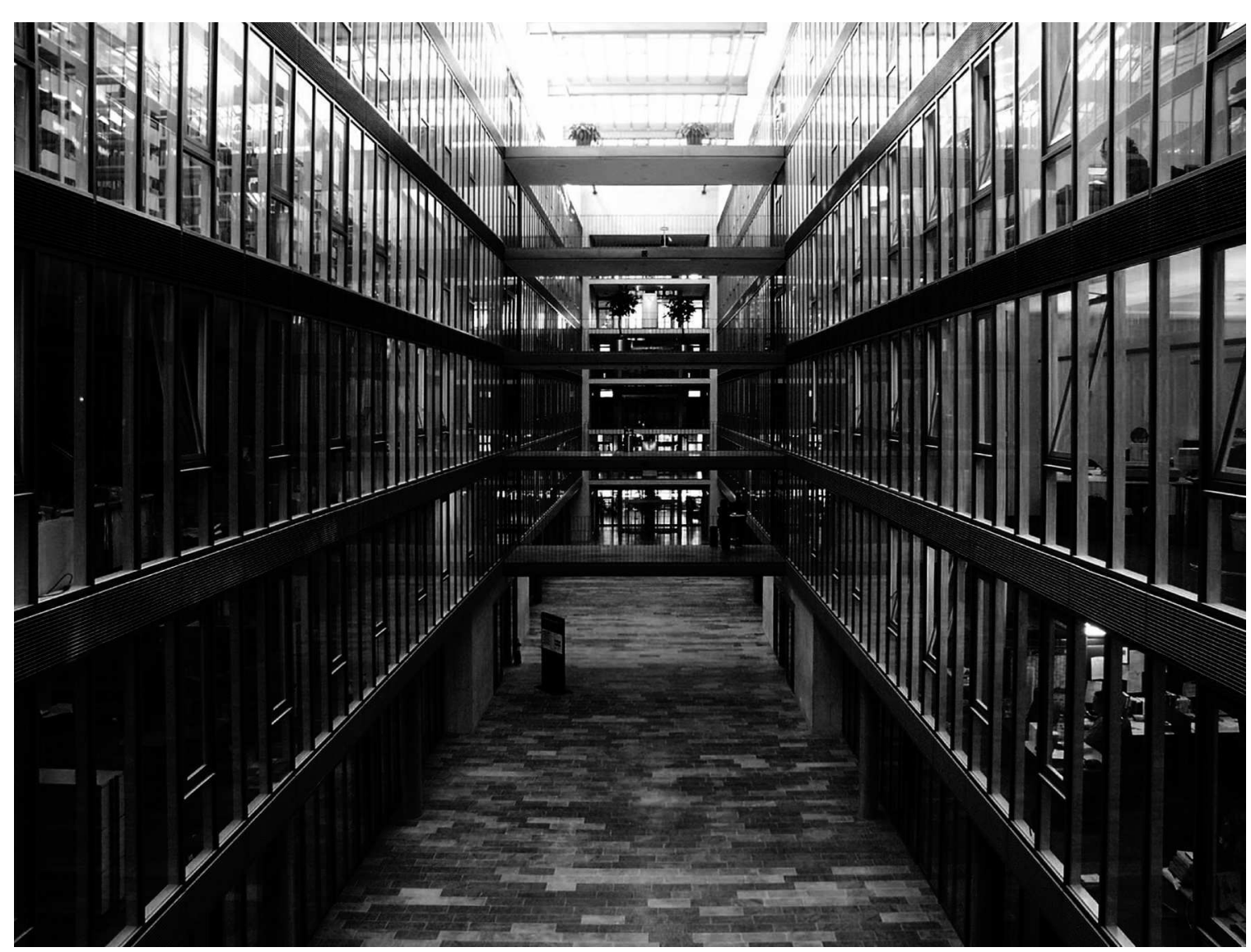

Figure 4.

Fünf Höfe, Munich. Source: https://commons.wikimedia.org

the formative dynamics of the "knotting".

In this case, the most interesting aspect is that -even if shōtengais are something tightly connected to the Japanese culture- the phenomenon is architecturally comparable to other examples, even when the geographical context changes. Similarly to the passages, most of these pathways are in fact obtained by "overturning" the commercial function (originally present on a main urban axis) within an urban fabric, often on the roadway of a path, parallel to the generator one, but hierarchically lower. Differently from passages, however, shōtengais do not occupy the residual space within the lots, but use to colonize a roadway, which specializes in situ involving in this process the surrounding fabric (usually residential), which modifies its nature. As a result of this transformation there is in fact a densification of the road segment, which is connected to the urban fabric, by "covering up" and creating a new organism. In this sense, the shōtengai modifies its own "external" status, becoming an internal place, architecturally connoted (interior façades are recreated even if without the splendor and lexical wealth of the passage) and covered by windows and skylights, similarly to the western examples. Because of its size, however, the shōtengai never reaches a typological autonomy but, similarly to the bazaar, it determines the specialization of an urban fabric that preserves all the characteristic features of the basic building it is made of, while actually being configured as an inner place, distinct from the rest of the city.

The exceptional nature of shōtengais is established precisely due to the relationship with the building fabric, primarily because the residential function (often present), it is not found in other similar forms of commercial fabric; moreover, in many segments it is easy to see how residences and shops are oriented orthogonally to the commercial route, from which it follows that they were built starting from this path and not previously, suggesting 
the generative autonomy of the shōtengai in relation to the urban form.

\section{Conclusion}

In conclusion, we can observe how the diversification of roles between outer urban spaces - related to traffic - and internal urban spaces - linked to commerce - produces linear organisms, connected to the morphology of the city, but similar to each other since they both are an expression of a common human need. Even today, the contemporary city requires internal places in which to satisfy the need related to trade and sociality, since the outdoor spaces, as "traditional" squares, are almost disappearing in some contexts, while in others - as for example in Eastern Asia and in North America - they do not constitute a prevalent component of the urban fabric. The international diffusion of the mall as a contemporary bazaar is an emblematic example of the typological crisis faced by the commercial fabric and of the possible future developements.

\section{Notes}

1 It is important to clarify how, even before the massive diffusion of the commercial covered walkways in London, Brussels, Paris, Munich, etc, it was widely used the so-called halle (hall in English), a covered market characterized by a polar configuration. The Italian researcher Donatella Calabi underlines that the term "halle" refers to a "(...) covered construction (in the past it has had also an open shape) related to trade or commerce, storage, bargaining, and exhibition, in which many sellers exercised their activities. The halle was widely spread between the 12th and the 13th century, especially in France, England and the Netherlands but, considering the Eastern bazaar, we can find a good number of examples also in the Mediterranean countries" (Calabi, 1993).

2 "The term knotting indicates the architectural outcome of connecting together the different elements of a structure, in order to form a spatial knot within the architectural, or urban, organism. The knotting summarizes the arrangement of the 'building matter' around a center, following which, a knot -at the same time spatial, constructive and distributive- is originated. An example can be observed into the processes that preside over the formation of the Roman palace and their subsequent developments, as well as in the modern postal buildings, also generated through a knotting of paths, overturned around a central space. The knotting, which metaphorically refers to knots, is the outcome of a process that can be appreciated and defined only once it is concluded; the same dynamics presides over the formation of some specialized buildings, for which we can recognize a pre-formative phase (which contains the conditions for the final definition), some transitional phases of the new organism, and the codified type" (Falsetti, 2016).

\section{References}

Alfano, N. (2008) Città e case: Racconti di morfologia urbana, (Sellerio, Palermo).

Benevolo, L. (1975) Storia delle città 2 . La città medievale, (Editori Laterza, Rome, Bari).

Benjamin, W. (2002) I Passages di Parigi (Einaudi, Turin).

Calabi, D. (1993) Il mercato e la città. Piazze, strade, architetture d'Europa in età moderna (Saggi Marsilio, Padua).

Caniggia, G., Maffei G.L. (1982) Lettura dell'edilizia di base (Edizioni Alinea, Florence).

Ciotoli, G. (2017) Dal Grattacielo al Tessuto Verticale. Nuovi sviluppi architettonici e urbani, (Officina edizioni, Rome).

Ciotoli, P. (2017) 'Arcade d'oltreoceano: analogieedifferenzedellastrada commerciale in Gran Bretagna e in Nord America', in G. Belli, F. Capano, M. I. Pascariello (eds), La città, il viaggio, il turismo. Percezione, produzione e trasformazione, Conference Proceedings AISU 2017, (CIRICE, Napoli).

Ciotoli, P., Falsetti M. (2017) 'Resilient processuality: the commercial building typology from Bazaars to Passages', in Ding W., Hu Y., Guo P. (eds), Urban Morphology and the Resilient City: Proceedings of the 
23rd International Seminar on Urban Form, (Digital Media Press of Nanjing University, Nanjing), pp. 610-615.

Ciotoli, P. (2016) 'Vertical tissue: typological interpretation of the skyscraper' in AA.VV. (eds.), City as organism. New visions for urban life-ISUF Rome 2015. Conference Proceedings, (U+D Editions, Roma).

Falsetti M. (2017) Annodamenti. La specializzazione dei tessuti urbani nel processo formativo e nel progetto (FrancoAngeli Editore, Rome).

Falsetti, M. (2017) 'La doppia immagine:moderne internità urbane tra Parigi, Osaka e Las Vegas', in G. Belli, F. Capano, M. I. Pascariello (eds), La città, il viaggio, il turismo. Percezione, produzione e trasformazione, Conference Proceedings AISU 2017, (CIRICE, Napoli).

Falsetti M. (2016) 'Knottings' in AA.VV. (eds.), City as organism. New visions for urban life-ISUF Rome 2015. Conference Proceedings, (U+D Editions, Roma).

Figueira de Faria, M. (ed.) (2008) Praças Reais, (Livros Horizonte, Lisbon).

Geist, J.F. (1983) Arcades: a history of a building type (MIT Press, Cambridge MA).

Laroche, L. (2014) L'architecture commerciale à l'usage des villes: ambiances, pratiques et projets, tesi di dottorato, Architecture, aménagement de l'espace, unpublished $\mathrm{PhD}$ Thesis, Université de Grenoble.

Lemoine, B.(1989) Les passages couverts en France, (Delegation a l'action artistique de la ville de Paris, Parigi).

Lovero P. (2005) 'Un interno di "famiglia". La strada porticata', in AA.VV. (EDS), Atti del XIV Seminario di Camerino, (Agorà, La Spezia).

Maffei G.L., Maffei M. (2011) Lettura dell'edilizia speciale (Edizioni Alinea, Florence).

Maretto, P. (1993) Realtà naturale e realtà costruita, (Altralinea, Florence).

Navascués Palacio, P. (1993) La plaza mayor en España, (Cuadernos de Arte Español).

Niglio, O. (2016) Avvicinamento alla storia dell'architettura giapponese. Dal periodo Nara al periodo Meiji, (Aracne, Rome).

Romano M. (2004) Costruire le città, (Skira, Milan).
Strappa, G. (1995) Unità dell'organismo architettonico. Note sulla formazione e trasformazione dei caratteri degli edifici, (edizioni Dedalo, Bari).

Strappa, G. (2014) L'architettura come processo. Il mondo plastico murario in divenire, (FrancoAngeli Editore, Milan).

Whitehand, J.W.R. (ed.) (1981) The urban landscape: historical development and management. Papers by M.R.G. Conzen (Academic Press, London, New York). 